\title{
JOURNAL OF NUTRTIIIN CDLLEGE
}

Volume 11, Nomor 1, Tahun 2022, Halaman 1-5

Online di: http://ejournal3.undip.ac.id/index.php/jnc/

Submitted: 14 Desember 2020

Accepted: 19 November 2021

\section{IDENTIFIKASI POTENSI SENYAWA ISOFLAVON DAN QUERCETIN DAN PERBANDINGAN IKATAN TERHADAP ACE (ANGIOTENSIN-CONVERTING ENZYME) MENGGUNAKAN STUDI IN SILICO}

\author{
Choirun Nissa*, Guritan Indra Sukma, Indah Juliana Madjid, Nur Mariyah Sidin, Maulidatul Musyarrofah \\ Program Studi S1 Ilmu Gizi Sekolah Tinggi Ilmu Kesehatan Widya Cipta Husada \\ Jl. Jenderal Sudirman (Sidotopo) No. 11, Kepanjen, Kab. Malang, Jawa Timur, Indonesia \\ *Korespondensi: E-mail: nissachoirun88@gmail.com
}

\begin{abstract}
Background: The prevalence of hypertension in Indonesia is relatively high, around $29.1 \%$ in men and women at $26.6 \%$. The number of patients with hypertension in East Java is also relatively high, as many as 31,789 people. Alternative solutions in this study, utilizing isoflavone and quercetin as antihypertensive. Isoflavone and quercetin are phenolic compounds that able to bind ACE (Angiotensin Converting Enzyme) and affect blood pressure.

Objectives: This study identified the potential of isoflavone and quercetin compounds as well as a comparison between isoflavone and quercetin bonds to ACE using Hex 8 software.

Methods: This study was quantitative research using in silico method The results of molecular docking visualization were displayed with Discovery Studio software. The software used in this study was pass server and HEX 8.0.

Result: The results of this study indicate that the quercetin and isoflavone compounds have the potential effect as vaso protector, the inhibitory energy of isoflavone molecules against ACE is $-194.66 \mathrm{kcal} / \mathrm{mol}$, quercetin is $-236.47 \mathrm{kcal} /$ mol, captopril is $-494.56 \mathrm{kcal} / \mathrm{mol}$

Conclusion: It can be concluded that the binding energy of isoflavone and quercetin ligands against ACE (Angiotensin Converting Enzyme) are greater than that Captopril ligands against ACE (Angiotensin Converting Enzyme). The results of this study provide hope for the potential use of ligand compounds as antihypertensives but require further research.
\end{abstract}

Keywords: Anti-hypertension; Isoflavones; Quercetin; ACE (Angiotensin Converting Enzyme)

\begin{abstract}
ABSTRAK
Latar belakang: Prevalensi hipertensi di Indonesia tergolong tinggi, sekitar 29,1\% pada laki-laki dan perempuan sebesar 26,6\%. Penderita hipertensi di Jawa Timur juga tergolong tinggi, sebanyak 31.789 orang. Solusi alternatif dalam penelitian ini, memanfaatkan isoflavon dan quercetin sebagai antihipertensi. Isolavon dan quercetin merupakan seyawa fenolik yang mampu berikatan dengan Angiotensin Converting Enzyme (ACE) dan mempengaruhi tekanan darah.

Tujuan: Penelitian ini mengidentifikasi potensi senyawa isoflavon dan quercetin serta perbandingan ikatan antara isoflavon dan quercetin terhadap ACE dengan menggunakan perangkat lunak Hex 8.

Metode: Penelitian ini adalah deskriptif kuantitatif dengan penelusuran melalui metode in silico (pengunduhan molekul dan penambatan molekul) secara komputerisasi. Software atau aplikasi yang digunakan pada penelitian ini adalah pass server dan HEX 8.0.

Hasil: Hasil visualisasi penambatan molekul ditampilkan dengan perangkat lunak Discovery Studio. Hasil penelitian ini menunjukkan bahwa senyawa quercetin dan isoflavone berpotensi sebagai vasoprotektor. Energi penambatan molekul Isoflavon terhadap ACE sebesar -194,66 kkal.mol. Quercetin sebesar -236,47 kkal.mol, Captopril sebesar -494.56 $\mathrm{kkal} / \mathrm{mol}$.

Simpulan: Energi penambatan ligan isoflavon dan quercetin terhadap ACE (Angiotensin Converting Enzyme) lebih besar daripada penambatan ligan Captopril terhadap ACE (Angiotensin Converting Enzyme). Hasil penelitian ini memberi harapan potensi penggunaan senyawa ligan sebagai antihipertensi namun memerlukan penelitian lebih lanjut.
\end{abstract}

Kata Kunci: Anti-hipertensi; Isoflavon; Quercetin; ACE (Angiotensin Converting Enzyme)

\section{PENDAHULUAN}

Pada tahun 2010, hasil survei World Health Organization menunjukkan bahwa persentase penderita hipertensi paling banyak terjadi di negara berkembang. Penderita hipertensi tertinggi terdapat di Afrika dengan persentase sebesar 46\%. Selanjutnya diikuti dengan Asia Tenggara sebesar $36 \%$ dan Amerika sebesar 35\% juga mengalami hipertensi. Tingkat prevalensi hipertensi juga terjadi di Indonesia, yakni pada pria sebesar $29,1 \%$ dan pada 
wanita sebesar $26,6 \% .^{1}$ Menurut data Riset Kesehatan Dasar tahun 2013, prevalensi hipertensi di Indonesia ditentukan berdasarkan pengukuran tekanan darah pada penduduk dengan umur $\geq 18$ tahun. Hasil pengukuran pada umur $\geq 18$ tahun sebesar $25,8 \%{ }^{2}$

Penanganan untuk pasien hipertensi dapat dilakukan dengan dua cara yaitu terapi non farmakologi dan terapi farmakologi. Terapi non farmakologi dilakukan dengan cara menjaga pola hidup sehat seperti olahraga secara teratur, diet dan pola makan, berhenti merokok dan mengurangi asupan garam. ${ }^{3}$ Terapi farmakologi dapat dilakukan dengan memberikan anti hipertensi yang sesuai kondisi pasien. Angiotensin Converting Enzyme Inhibitors (ACEI) merupakan salah satu contoh terapi lini kedua. ACEI dapat menurunkan tekanan darah dan mengurangi resiko terjadinya komplikasi kardiovaskular. ${ }^{4}$ ACE inhibitor juga mencegah degradasi bradikinin dan menstimulasi sintesis senyawa vasodilator lainnya termasuk prostaglandin dan prostasiklin. ${ }^{5}$

Senyawa isoflavon dan quercetin termasuk golongan senyawa fenolik yang berfungsi sebagai antioksidan. Efektifitas isoflavon dan quercetin untuk menurunkan tekanan darah tinggi perlu diuji lebih lanjut. Bahan makanan yang memiliki kandungan fenolik dapat berkhasiat menurunkan tekanan darah melalui penghambatan dan penurunan ekspresi ACE. Salah satu golongan senyawa fenolik yang mempunyai aktivitas ACEI adalah isoflavon dan quercetin. Mekanisme penghambatan ACE oleh isoflavon dan quercetin dihasilkan melalui komponen fenolik yang berinteraksi dengan ACE. ${ }^{6}$

Beberapa tanaman obat telah diidentifikasi mampu menghasilkan efek antihipertensi dengan bekerja menghambat angiotensin converting enzyme sehingga digolongkan sebagai inhibitor ACE. Inhibitor ACE dari senyawa alami ini dinilai lebih aman dan ekonomis. Inhibitor ACE dari alam berasal dari golongan senyawa fenolik seperti isoflavon dan quercetin. $^{7}$ Terapi antihipertensi yang banyak digunakan masyarakat luas saat ini adalah obatobatan golongan ACEI seperti captopril, sedangkan ACEI dari senyawa-senyawa fenolik belum banyak digunakan sebagai terapi antihipertensi. Hal ini merupakan potensi bagi berkembangnya pangan fungsional maupun nutraceutical. Tujuan dari penelitian dapat mengetahui potensi senyawa isoflavon dan quercetin serta perbandingan ikatannya terhadap ACE.

\section{METODE}

Desain penelitian yang digunakan pada penelitian ini adalah deskriptif kuantitatif dengan penelusuran melalui metode in silico (pengunduhan molekul dan penambatan molekul) secara komputerisasi. Software atau aplikasi yang digunakan pada penelitian ini adalah pass server dan HEX 8.0. Identifikasi potensi senyawa dilakukan online menggunakan aplikasi pass server http://www.pharmaexpert.ru/passonline/predict.php , dengan cara mengunduh terlebih dahulu bentuk canonical smiles tiap senyawa yang diunduh dari Pubchem (https://pubchem.ncbi.nlm.nih.gov/). Potensi senyawa yang baik ditunjukkan dengan nilai Probability activity $(\mathrm{Pa})$ dengan rentang nilai 0 sampai dengan 1. Apabila nilai $\mathrm{Pa}>0,7$ maka perkiraan secara laboratorium akan sesuai dengan uji komputasi.

Prosedur pengunduhan senyawa isoflavon, quercetin dan captopril sebagai ligan tediri atas pengunduhan dan pembuatan ligan serta optimasi ligan. Ligan dibuat dalam format $\mathrm{pdb}$, dan ligan diunduh dari situs http://PubChem.ncbi.nlm.nih.gov. Format ligan tersebut diubah menjadi pdb menggunakan open babel. Selanjutnya struktur ligan yang telah dibuat, kemudian dioptimasi dengan menggunakan open babel. Kemudian, buka ligan yang telah dibuat (ligan $\rightarrow$ input $\rightarrow$ open $\rightarrow$ convert), setelah itu simpan dalam bentuk pdb (ligan output $\rightarrow$ save as $p d b \rightarrow$ save).

Senyawa ACE yang bertindak sebagai makromolekul diunduh dari Protein Data Bank. Data makromolekul diunduh dalam format text. Makromolekul ACE yang telah diunduh harus dipisahkan terlebih dahulu dari pelarut dan ligan atau residu non standar. Pemisahan makromolekul ACE dari molekul air dan ligan yang tidak diperlukan dilakukan dengan menggunakan program Discovery Studio 2019. Hasil pemisahan makromolekul ACE atau ACE murni disimpan dalam format pdb. Selanjutnya optimasi makromolekul dilakukan dengan menggunakan open babel dan buka makromolekul yang disimpan dalam format.pdb (file $\rightarrow$ read molecule $\rightarrow$ pdb.)

Penambatan molekul dengan ligan dilakukan dengan menggunakan Hex 8.0. Langkah pertama membuka file makromolekul ACE yang sudah dioptimasi dalam bentuk pdb (file $\rightarrow$ open $\rightarrow$ molekul $\rightarrow$ lokasi file ACE). Kemudian buka file ligan yang diujikan (file $\rightarrow$ open $\rightarrow$ ligan $\rightarrow$ lokasi file ligan). Langkah ketiga buka control lalu pilih docking. Visualisasi interaksi makromolekul dan ligan dapat dilihat dengan menggunakan program discovery studio 2019 dalam bentuk gambar penambatan molekul. Hasil kalkulasi docking dilihat pada hasil output yang ditampilkan dalam visualisasi gambar dengan nilai Root Mean Square Deviation (RMSD) dan energi docking dari penambatan molekul.

Hasil uji in-silico berupa skor docking dan nilai Root Mean Square Deviation. Syarat dikatakan 
metode yang digunakan itu baik atau valid memiliki nilai RMSD $\leq 2 \AA ̊$. Skor docking menunjukkan nilai energi ikatan $(\Delta \mathrm{G})$. Semakin kecil $\Delta \mathrm{G}$, ikatan semakin kuat.

HASIL

\section{Identifikasi potensi senyawa}

Quercetin memiliki aktivitas sebagai vasoprotektor yang lebih tinggi dibandingkan dengan isoflavon. Hal ini ditunjukkan pada Gambar 1. Nilai probability activity quercetin sebagai vasoprotektor sebesar 0,824 sedangkan isoflavon sebesar 0,723.

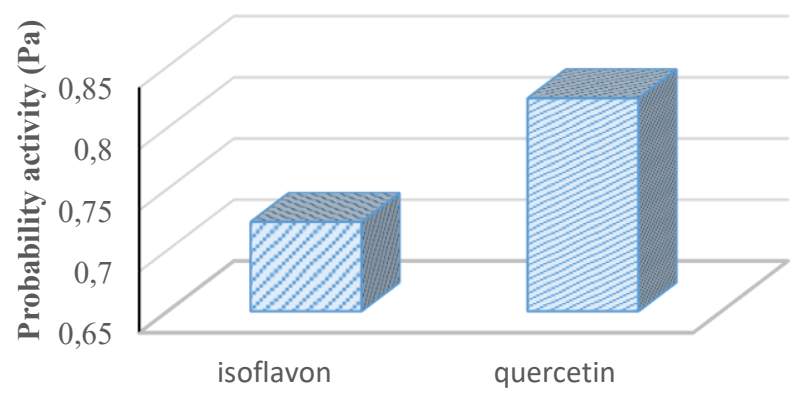

Gambar 1. Potensi Vasoprotektor Senyawa Quercetin dan Isoflavon

Deskripsi ligan isoflavone dan quercetin serta makromolekul Angiotensin- Converting Enzyme (ACE)

Bentuk isoflavon dalam situs molinspiration memiliki berat molekul 200.00 sma dan logPnya sebesar 3.54. Bentuk 3D quercetin setelah dikonversikan dalam format .pdb. Bentuk 3D dari quercetin dapat dilihat menggunakan Discovery
Studio dan dicocokkan dengan bentuk quercetin dalam situs Pubchem.com. Berat molekul quercetin yaitu 240,08 dan $\log \mathrm{P}$ 1,68 dengan menggunakan molinspiration. Bentuk ACE (AngiotensinConverting Enzyme) dalam situs molinspiration memiliki berat molekul 346.14 sma dan logPnya 0.65 .

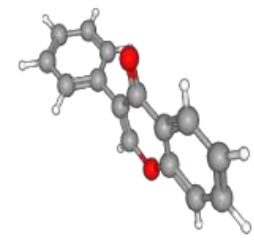

Gambar 2. Bentuk 3D Isoflavon

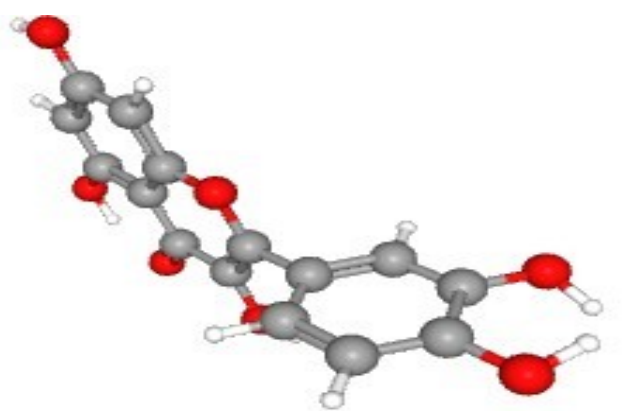

Gambar 3. Bentuk 3D Quercetin

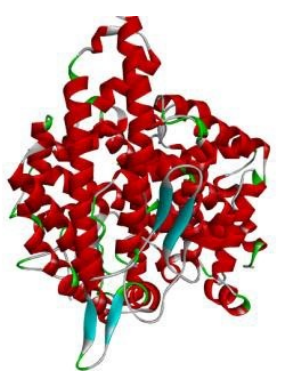

Gambar 4. Struktur ACE

\section{Perbandingan Energi Ikatan terhadap ACE}

Hasil penambatan senyawa ligan isoflavone dengan makromolekul ACE menggunakan perangkat lunak Hex 8.0 memiliki nilai RMSD 1 Á dan nilai energi yang dihasilkan sebesar $-194.66 \mathrm{kkal} / \mathrm{mol}$. Hasil docking akan dimasukkan pada perangkat discovery studio 2019 yang di tampilkan dalam Gambar 5. Sedangkan hasil penambatan senyawa ligan quercetin dengan makromolekul ACE menghasilkan nilai energi dan RMSD yaitu $-236,47 \mathrm{kkl} / \mathrm{mol}$ dan 1,00. Hasil docking akan dimasukkan pada perangkat discovery studio 2019 yang di tampilkan dalam Gambar 6.

Adapun perbandingan energi ikatan antar senyawa dan ligan obat pembanding yang digunakan dalam penelitian ini yaitu captopril ditampilkan dalam Tabel 1. Hasil penambatan molekul dengan menggunakan perangkat lunak Hex 8.0 pada Tabel 1, menunjukkan hasil penambatan senyawa isoflavon yang ditambatkan terhadap ACE menghasilkan energi sebesar $-194.66 \mathrm{kkal} / \mathrm{mol}$, hasil penambatan senyawa quercetin yang ditambatkan terhadap ACE, menghasilkan energi sebesar - 236,47 $\mathrm{kkal} / \mathrm{mol}$ sedangkan captopril yang ditambatkan terhadap ACE memperoleh hasil $-494.56 \mathrm{kkal} / \mathrm{mol}$. Nilai RMSD untuk masing-masing ligan yaitu -1 dan 1 Á. Dengan demikian menunjukkan bahwa energi yang dihasilkan oleh senyawa ligan isoflavon dan quercetin lebih besar daripada energi yang dihasilkan oleh senyawa pembanding yaitu captopril. 

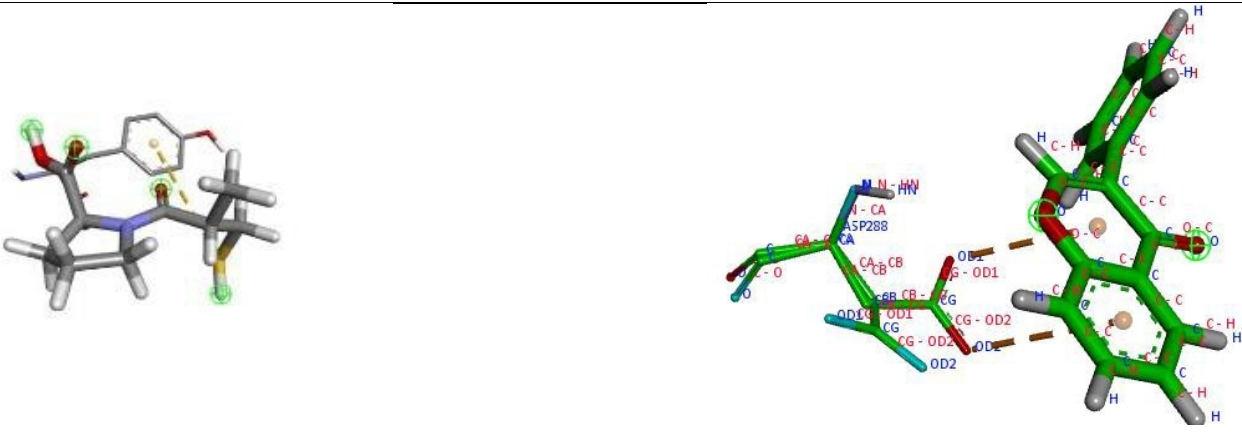

Gambar 5. Visualisai Ikatan Isoflavon dengan ACE

Gambar 6. Visualisasi Ikatan Quercetin terhadap ACE

Tabel 1. Hasil Penambatan Molekul

\begin{tabular}{lcc}
\hline Hasil Penambatan & RMSD & $\Delta$ Gbind docking $(\mathrm{kkal} / \mathrm{mol})$ \\
\hline ACE dengan isoflavon & $1 \AA$ & -194.66 \\
ACE dengan quercetin & $1,00 \AA$ & $-236,47$ \\
ACE dengan captopril & $-1 \AA$ & -494.56 \\
\hline
\end{tabular}

\section{PEMBAHASAN}

Aktivitas quercetin sebagai vasoprotektor lebih tinggi diabndingkan isoflavon. Hal ini sesuai dengan penelitian L Actis-Goretta Tahun 2006 bahwa quercetin merupakan flavonoid dalam bahan pangan yang memiliki aktivitas kuat sebagai vasodilator dan vasoprotektor. ${ }^{8}$ Isoflavon merupakan senyawa fenolik yang banyak terkandung dalam olahan kacang kedelai seperti tempe dan tahu. Hasil pengunduhan isoflavon dengan berat molekul isoflavone yang diperoleh dari molinspiration.com sebesar 200 sma dan $\log \mathrm{P}$ senilai 3.54. Berat molekul dan $\log \mathrm{P}$ ini menentukan kemampuan isoflavon berikatan dengan ACE, sebab syarat agar ligan dapat berikatan dengan reseptor target jika berat molekulnya kurang dari 500 sma dan $\log \mathrm{P}$ $\leq 5 .{ }^{9}$ Hasil deskripsi ligan isoflavon menunjukkan berat molekul isoflavon kurang dari 500 sma dan $\log \mathrm{P}$ kurang dari 5, sehingga memungkinkan isoflavon mampu berikatan dengan ACE.

Hasil penelitian menggambarkan bahwa quercetin mampu berikatan dengan ACE, sehingga quercetin berpotensi untuk menghambat $\mathrm{ACE}$ dan quercetin bisa dijadikan obat. Quercetin merupakan senyawa fenolik yang banyak terkandung pada apel, kacang kedelai, buah beri dan bawang. Quercetin dalam buah apel berfungsi sebagai antioksidan yang diketahui memilki aktifitas anthi-hipertensi. Hal ini sejalan dengan penelitian Novita Tahun 2016, menyatakan bahwa efek quercetin terhadap tekanan darah dengan cara menghambat enzim ACE sehingga berpotensi sebagai anti-hipertensi. ${ }^{10}$ Hasil penelitian ini juga sejalan dengan penelitian yang dilakukan oleh Widiasari Tahun 2015 bahwa quercetin pada tempe kacang kedelai mampu menghambat aktivitas ACE yaitu menurunkan tekanan darah secara in vitro. ${ }^{11}$

Angiotensin converting enzym memiliki peran yang penting dalam mekanisme pengaturan tekanan darah. Produk yang dihasilkan oleh enzim ini adalah angiotensin II, yang merupakan senyawa penting yang berperan dalam vasokontriksi pembuluh darah. Kadar angiotensin II pada penerita hipertensi mengalami peningkatan. Tekanan darah akan menurun apabila kadar angiotensin mengalami penurunan. Mekanisme ini menjadi dasar teori pengembangan obat yang bekerja dengan berikatan pada sisi aktif ACE sehingga angiotensin yang memproduksi angiotensin II dapat dihambat. ${ }^{12}$

Hasil energi ikatan semua senyawa ligan terhadap ACE lebih besar daripada captopril terhadap ACE. Hasil penambatan ligan uji menunjukkan kurang baik atau kurang stabil daripada ligan pembanding. Senyawa alami yang ditambatkan pada ACE semuanya mempunyai hasil yang lebih tidak stabil bila dibandingkan dengan senyawa pembanding dari obat antihipertensi standar yaitu captopril. Penyebabnya adalah struktur kimia dari captopril dapat diatur karena merupakan obat atau ligan sintetis, tetapi efek samping dari penggunaan obat sintetis jangka panjang dapat menimbulkan efek negatif dalam tubuh yaitu memperberat fungsi hati, sehingga hasil penelitian ini dapat memberi harapan kemungkinan penggunaan senyawa ligan sebagai antihipertensi namun memerlukan penelitian lebih lanjut.

\section{SIMPULAN}

Isoflavon yang ditambatkan terhadap ACE Isoflavon dan quersitin mempunyai potensi sebagai vasoprotektor yang tinggi. Hasil 
visualisasi interaksi ikatan baik isoflavon maupun quercetin terhadap ACE menunjukkan bahwa isoflavon dan quercetin mampu berikatan dengan ACE. Energi penambatan isoflavon dan quercetin lebih besar dan lebih tidak stabil dibandingkan captopril. Hasil analisa dan visualisasi interaksi ligan dengan reseptor menunjukkan bahwa senyawa ligan ini mempunyai potensi untuk berikatan dengan ACE sebagai antihipertensi, namun masih perlu adanya penelitian lanjutan. Saran penelitian ini adalah perlu adanya penelitian lanjutan pada tahap in vitro/in vivo ataupun penelitian klinis lanjutan terkait dengan efek fisiologis maupun uji dosis antihipertensi dari senyawa isoflavon dan quercetin

\section{UCAPAN TERIMA KASIH}

Ucapan terima kasih disampaikan kepada LPPM STIKes Widya Cipta Husada yang telah memberikan fasilitas dan motivasi terselesaikannya program penelitian ini.

\section{DAFTAR PUSTAKA}

1. Hussain MA, Al Mamun A, Reid C, Huxley RR. Prevalence, awareness, treatment, and control of hypertension in Indonesian adults aged $\geq 40$ years: findings from the Indinesia Family Life Survey (IFLS). Plos One. 2016; 11(8):1-16. https://doi.org/10.1371/journal.pone.0160922.

2. Departemen Kesehatan RI. Riset Kesehatan Dasar 2013. Riset Kesehatan Dasar 2013. Jakarta; 2013.

3. Ainurrafiq A, Risnah R, Azhar MU. Terapi non farmakologi dalam pengendalian tekanan darah pada pasien hipertensi: systematic review. Media Publiaksi Promosi Kesehatan Indonesia. 2019; 2 2(3): $192 \quad-199$. https://doi.org/10.31934/mppki.v2i3.806

4. Timur WW, Andayani TM, Aribawa R. analisis efektivitas-biaya kombinasi antihipertensi oral pasien hipertensi rawat jalan di Rumah Sakit Umum Daerah Tugurejo Semarang. Sains Medika. 2012; 4 (2): 124 - 133.

5. Wahyuningsih E. Evaluasi penggunaan obat antihipertensi pada pasien gagal ginjal kronik rawat inap di rumah sakit umum daerah provinsi nusa tenggara barat. Mataram: Universitas Muhammadiyah Mataram; Skripsi: 2019.

6. Asif M, Khodadadi E. Medicinal uses and chemistry of flavonoid contents of some common edible tropical plants. J Paramed Sci. 2013; 4(3) : $\quad$ 119-138. https://doi.org/10.22037/jps.v4i3.4648

7. Yanti AR, Rahayu ST, Mahayasih PG, Januarko MU. Standardization of Indonesian Traditional
Antihypertensive Medicines (Jamu) through the ACE Inhibitor Mechanism. Pharmacogn J. 2020; 12(3): 422-429. https://doi.org/10.5530/pj.2020.12.65

8. Actis-Goretta L, Ottaviani JI, Fraga CG. Inhibition of angiotensin converting enzyme activity by flavanol-rich foods. J Agric Food Chem. 2006; 54(1): 229 - 234. htpps://doi.org/ 10.1021/jf052263o

9. Apriani F. Studi Penambatan Molekul Senyawa - senyawa Amidasi Etil ParaMetokisinamat Pada Peroxisome Proliferator- Activate ReceptorGamma (PPAR $\gamma$ ). Jakarta: UIN Syarif Hidayatullah; Skripsi: 2015.

10. Carolia N, Ghaisani UM. Psidium guajava sebagai Antihipertensi dan Antihiperlipidemia: Efek pada Penurunan Tekanan Darah dan Pengontrol Profil Lipid. J Major. 2016; 5(1): 134-139.

11. Widiasari S. Mekanisme Inhibisi Angiotensin Converting Enzym Oleh Flavonoid Pada Hipertensi. Collab Med J. 2018;1(2): 30 - 44.

12. Desmiaty $\mathrm{Y}$, Rahmat D, Rainoer AN. In Vitro ACE Inhibitory Activity and Total Flavonoids Quantification of Ethanolic Extract of Pletekan (Ruellia tuberosa L.) Leaves. Dalam Prosiding: International Symposium on Traditional Medicine. 4-6 Juni 2014; Tawangmangu; B2P2TOOT; 2014. 